\title{
Peertechz
}

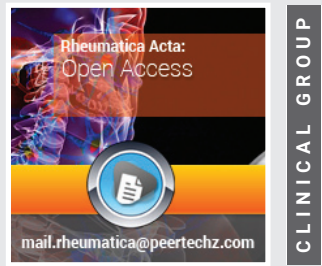

Rheumatica Acta:OPen Access

Opinion

\section{Why does the new disease activity score (EgyDAS) of Rheumatoid Arthritis not}

\section{function?}

Accepted: 23 January, 2021

Published: 25 January, 2021

*Corresponding author: Yuri Muravyev, VA Nasonova Research Institute of Rheumatology, 34A Kashirskoye highway, Moscow 115522, Russia,

E-mail:murawyu@mail.ru

ORCID: https://orcid.org/0000-0001-5394-883X https://www.peertechz.com

Check for updates

\section{Muravyev YV ${ }^{1 *}$, Muravyeva LA ${ }^{2}$, Glukhova SI ${ }^{1}$ and Litvinova MA $^{1}$}

'VA Nasonova Research Institute of Rheumatology, 34A Kashirskoye highway, Moscow 115522, Russia

${ }^{2}$ Central Polyclinic Department of MBUZ [Municipal Budgetary Healthcare Institution], Khimki Central

Clinical Hospital, 2/21 Chkalova St., Khimki, Moscow region 141401, Russia

The analysis of almost a century-long evolution of ideas about the criteria for the activity of Rheumatoid Arthritis showed that the developed complex indices for determination there of are far from perfect, in particular the Disease Activity Score 28 (DAS28), widely used in clinical practice [1]. Therefore, the recently developed new Disease Activity Score (EgyDAS) of Rheumatoid Arthritis [2] has attracted interest because it includes four laboratory markers of Rheumatoid Arthritis (RA) activity, as opposed to DAS28, which assesses only one laboratory marker. It is the authors' opinion that EgyDAS is not only more accurate and easy to apply, but also "has both diagnostic/prognostic values in patient with RA". Because "a subject has a low Egyscore $<-0.79$, he/she can be considered to not have RA disease ".

Therefore, we decided to put the new disease activity score into practice. For this purpose, a pilot study of medical documents of 9 women with RA, aged 28 to 67 years, was carried out, fulfilled the American College of Rheumatology (ACR) criteria for RA and observed in the V. A. Nasonova Research Institute of Rheumatology.

Having applied the EgyDAS offered by the authors, we have calculated the RA activity (Table 1 ).

- $\quad$ Remission $\leq-0.15$;

- Low disease activity $>-0.15-0.15$

\begin{tabular}{|c|c|c|c|c|c|c|}
\hline \multicolumn{5}{|c|}{ Laboratory activity markers } & \multirow{2}{*}{ EgyDAS } & \multirow{2}{*}{$\begin{array}{c}\text { RA activity } \\
\text { classification }{ }^{\star \star \star \star \star}\end{array}$} \\
\hline & ESR* & CRP** & PDW*** & MPV*** & & \\
\hline 1 & 22 & 30.2 & 10.8 & 9.5 & -0.09251 & Remission \\
\hline 2 & 9 & 6.3 & 11.9 & 10.3 & -1.48257 & $?$ \\
\hline 3 & 11 & 0.5 & 11.6 & 10.1 & -2.25683 & $?$ \\
\hline 4 & 106 & 119 & 12.7 & 10.7 & 1.159325 & High \\
\hline 5 & 16 & 9.3 & 15.4 & 12.1 & -1.20025 & $?$ \\
\hline 6 & 5 & 1.5 & 11.2 & 9.9 & -2.33987 & $?$ \\
\hline 7 & 31 & 1.7 & 14.9 & 11.3 & -1.21942 & $?$ \\
\hline 8 & 16 & 5.7 & 11.9 & 10.3 & -1.14561 & $?$ \\
\hline 9 & 18 & 1.1 & 12.1 & 10.3 & -1.65979 & $?$ \\
\hline
\end{tabular}

*Erythrocyte sedimentation rate (Westegren), mm/hr; **: C-reactive protein,mg/l $\star \star \star$ : Platelet distribution width, \%; $; \star \star \star$ : Mean platelet volume, $\mathrm{f} ; \star \star \star \star \star$ : Using the same criterion of DAS28 to measure the disease activity of a patient EgyDAS limits as follows [1].

- Moderate disease activity $>0.15-1.1$;

- High disease activity $>1.1$.

The assessment of the same RA patients in the same sequence, but according to DAS28, completed within the same period of time is represented in Table 2.

- $\quad$ Remission $\leq 2.6$;

- $\quad$ Low disease activity $>2.6-3.2$;

- $\quad$ Moderate disease activity $>3.2-5.1 ;$ 
Table 2: RA patients' activity according to DAS28.

\begin{tabular}{|c|c|c|c|c|c|c|}
\hline \multicolumn{5}{|c|}{ Test characteristic } & \multirow{2}{*}{ DAS28 } & RA activity \\
classification ${ }^{\star * * *}$
\end{tabular}

*:Tender joint count(0-28); **: Swollen joint count(0-28); ***: VAS general health patient $(\mathrm{mm})$; $* \star \star \star$ : Disease activity was categorized according to DAS28 score into one of the following [3].

\section{- $\quad$ High disease activity $>5.1$}

It is very unfortunate that the comparison of the results represented in Tables 1,2 allows us speaking about the impossibility of using the published EgyDAS formula in clinical practice.

Therefore, we limited the number of cases.

Hopefully, this is due to a typo in the final release of the article.

\section{References}

1. Muraviov YuV , Muraviova LA (2020) Saga of the Rheumatoid Arthritis Activity Criteria. EC Orthopaedics 11: 118-126. Link: https://bit.ly/3peW4vU

2. Khaled SAA, NasrEldin E, Makarem YS, Mahmoud HFF (2020) Value of Platelet Distribution Width and Mean Platelet Volume in Disease Activity Score of Rheumatoid Arthritis. J Inflamm Res 13: 595-606. Link: https://bit.ly/2Np7D5n

3. Aletaha D, Nell VP, Stamm T, Uffmann M, Pflugbeil S, et al. (2005) Acute phase reactants add little to composite disease activity indices for rheumatoid arthritis: validation of a clinical activity score. Arthritis Res Ther 7: R796- R806. Link: https://bit.ly/365Eumm

\section{Discover a bigger Impact and Visibility of your article publication with} Peertechz Publications

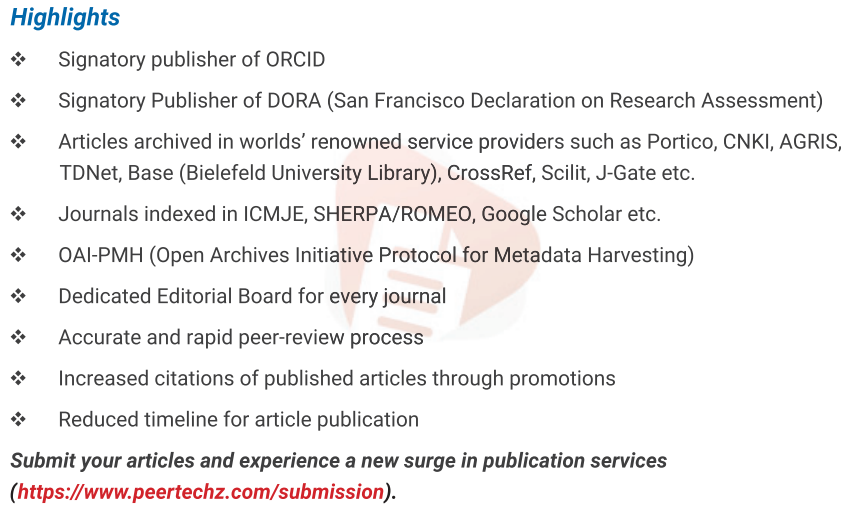

Peertechz journals wishes everlasting success in your every endeavours.

Copyright: @ 2021 Muravyev YV, et al. This is an open-access article distributed under the terms of the Creative Commons Attribution License, which permits unrestricted use, distribution, and reproduction in any medium, provided the original author and source are credited. 